\title{
ORIENTASI INTI BATUAN HASIL PEMBORAN PADA RANCANGAN LERENG TAMBANG EMAS TERBUKA ARAREN DI PT. TAMBANG TONDANO NUSAJAYA, SULAWESI UTARA
}

\section{ROCK CORE ORIENTATION ON THE OPEN PIT SLOPE DESIGN OF ARAREN GOLD MINE, PT. TAMBANG TONDANO NUSAJAYA, NORTH SULAWESI}

\author{
Imanuel Seru' ${ }^{1}$, Zufialdi Zakaria², Dicky Muslim² \\ ${ }^{1}$ Program Pascasarjana (S2), FTG-UNPAD JI. Dipati Ukur No. 35, Bandung \\ ${ }^{2}$ Fakultas Teknik Geologi, Universitas Padjadjaran, Bandung \\ Email: Imanuel.Seru@yahoo.co.id
}

SARI

Makalah ini mempresentasikan pendekatan penyelidikan geoteknik untuk mengetahui sebaran orientasi bidang diskontinuitas di bawah permukaan melalui pemboran geoteknik dengan orientasi inti batuan (rock core orientation) sebagai tahap awal pada rancangan lereng tambang emas terbuka Araren. Tiga lubang bor ditempatkan pada bagian timur, selatan, dan barat pada rancangan lereng akhir tambang terbuka. Metoda pemboran inti dimulai dari permukaan untuk mengumpulkan informasi massa batuan dan bidang diskontinuitas. Orientasi bidang diskontinuitas pada inti batuan hasil pemboran (oriented core) digunakan untuk mengamati potensi masalah kestabilan jenjang pada lereng batuan. Hasil penelitian menunjukkan bahwa potensi longsoran bidang, baji, dan rebah berpeluang terjadi dan tersebar pada lereng tambang di lokasi pengamatan.

Kata kunci: orientasi inti batuan, bidang diskontinuitas, lereng batuan, longsoran bidang, longsoran baji, longsoran rebah.

\begin{abstract}
This paper presents approach of geotechnical investigation as early stage to identify sub surface discontinuity distribution of structural geology as the early stage for Araren open pit slope design. Three drill holes are located at the eastern, southern, and western sides of the designed final pit wall. Core drilling method commenced from ground surface to collect rock mass and discontinuities plane information. The measured discontinuities orientations on drilled rock core (oriented core) may be utilized to observe potential bench stability problem of rock slopes. Result of this study showed planar, wedge, and toppling failures potential to occur and distribute well on the rock slope at observation area.
\end{abstract}

Keywords: rock core orientation, discontinuity plane, rock slope, planar, wedge failure, toppling failure. 


\section{MAKALAH ILMIAH}

\section{Literatur Geologi Daerah Penelitian}

Wilayah PT. Tambang Tondano Nusajaya (PT. TTN) terdapat di sebuah jalur endapan vulkanik yang termineralisasi kuat dan daerah intrusi yang kuat mengikuti Jalur Magmatik Mindanou Timur - Sulawesi. Jalur awal Miosen - Kuarter tersebut terbentuk oleh tumbukan ke arah barat terhadap lempeng bagian timur Asia Tenggara, (Grose, 1997). Cebakan emas terbentuk dalam lapisan andesit vulkanik kala Miosen Akhir - Pliosen yang tertutup lapisan tefra Kuarter dan endapan vulkanik andesit porfiritik sebagai batuan penyusun utama. Penyebaran dan sifat geologi dari semua jenis urat dan cebakan emas secara keseluruhan hampir sama.

Bagian struktur utama dari daerah cebakan Batupangah adalah brittle fault dan rekahan-rekahan yang menunjukkan arah mineralisasi utara-selatan dan baratlaut-tenggara. Struktur ini disimpulkan sebagai patahan blok normal (normal block faults) dengan kemiringan umumnya lebih besar dari 60 derajat. Grose (1997) menjelaskan bahwa pergerakan patahan mendatar dekstral yang kecil telah membuka beberapa patahan yang menyebabkan penebalan signifikan pada bagian dari mineralisasi urat, terutama di lipatan (flexure) pada struktur batuan induk (host rock).

Cebakan emas terbentuk dari dua urat yang hampir sejajar dengan lebar $1 \mathrm{~m}$ hingga $7 \mathrm{~m}$ berarah utara-selatan. Pengeboran eksplorasi dengan total panjang kedalaman lebih dari $15.000 \mathrm{~m}$ di sepanjang strike vein dengan kedalaman titik bor antara $150 \mathrm{~m}$ hingga $350 \mathrm{~m}$ dilakukan pada cebakan urat bagian barat (Majapahit) dan di bagian timur (Sriwijaya). Urat Sriwijaya berada kurang lebih $100 \mathrm{~m}$ sebelah timur dari urat Majapahit, urat tersebut bersambung di bagian selatan. Sistem urat di Araren miring hampir vertikal ke arah timur (Gambar 1).

Analisa struktur regional dari pola kelurusan foto ditunjukan dalam Gambar2. Dua koridor rekahan berarah utarautara timur laut yang dapat terlihat pada foto, yaitu koridor rekahan berarah selatan tenggara dan yang kedua utara-utara timur laut yang mencakup prospek Araren. Interpretasi struktur gambar SPOT mengidentifikasi arah kelurusan yang sama, namun set berarah baratlaut lebih banyak terlihat (Lockett, 1996). 


\section{MAKALAH ILMIAH}

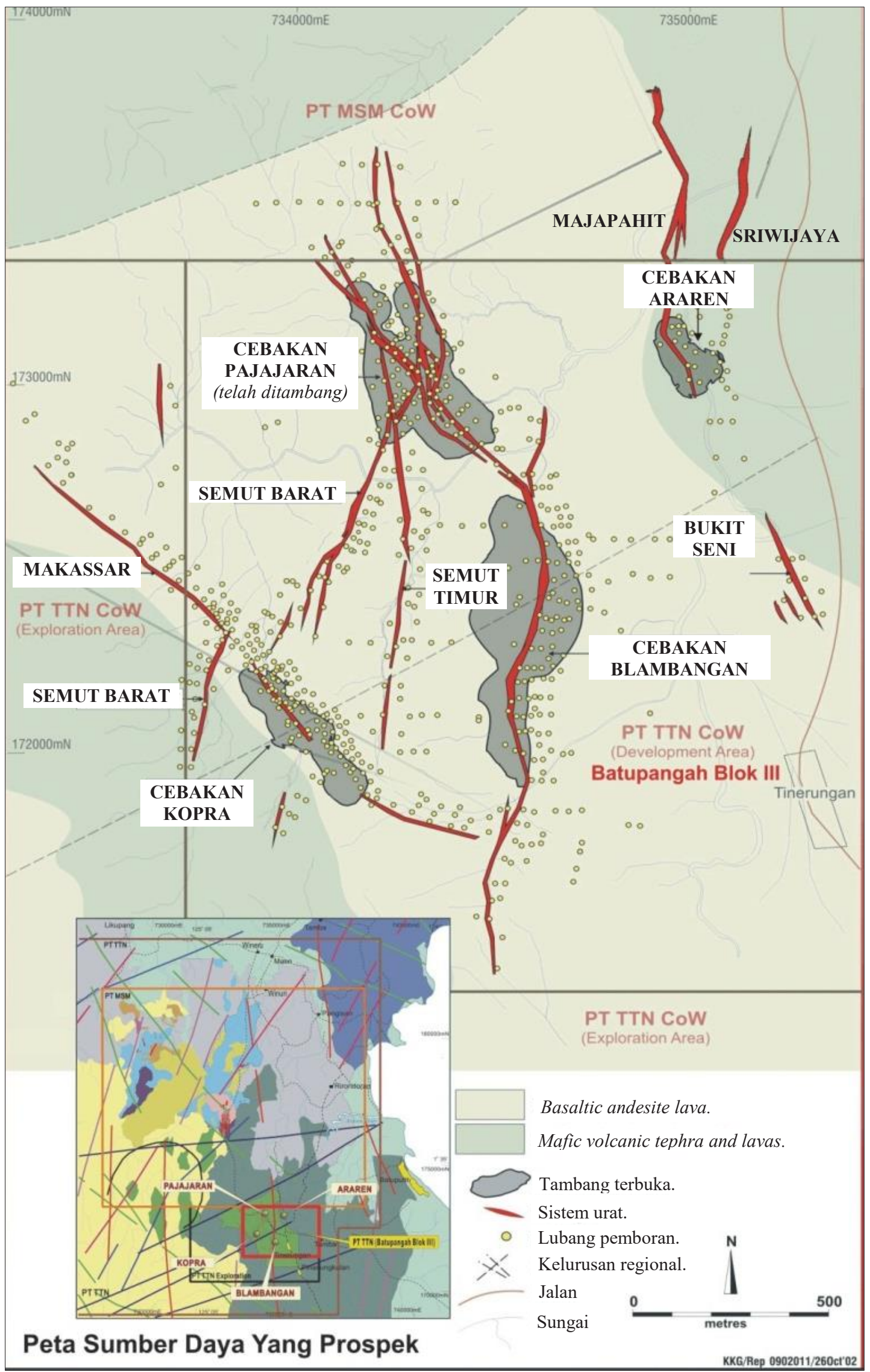

Gambar 1. Daerah cebakan Batupangah (Anonim, 2006). 


\section{MAKALAH ILMIAH}

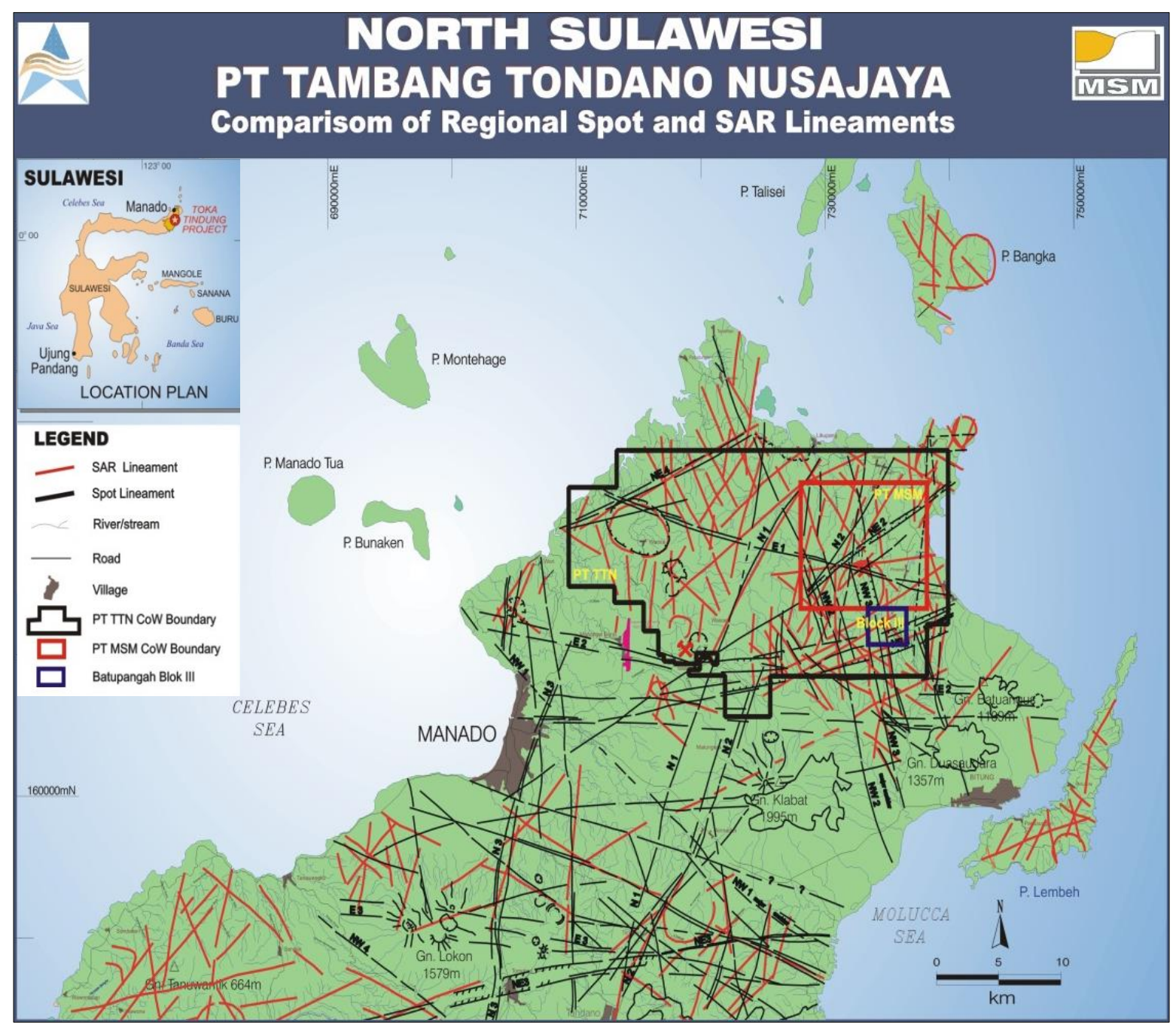

Gambar 2. Perbandingan pola kelurusan citra SAR (synthetic Aperture Radar) dan SPOT (Anonim, 2006).

\section{Metode Penelitian}

Persiapan. Mengumpulkan informasi yang telah dilakukan oleh para peneliti sebelumnya mengenai hal yang berhubungan dengan penelitian. Persiapan dan studi peta yang dibutuhkan di antaranya adalah peta topografi dan rancangan tambang terbuka. Menentukan lokasi dan rancangan pemboran geoteknik dilakukan pada tahap ini. Rancangan lubang bor pada 2015 diperlihatkan pada Tabel 1. Gambar 3 memperlihatkan posisi lubang pemboran geoteknik pada 1998 dan 2015 terhadap rancangan tambang terbuka. Gambar 4 (a), (b), dan (c) memperlihatkan penampang melintang setiap lubang pengeboran.

Tabel 1. Rancangan pemboran Geoteknik.

\begin{tabular}{ccccccc}
\hline \multirow{2}{*}{$\begin{array}{c}\text { Nomor ARSD } \\
\text { Lubang Bor }\end{array}$} & $\mathbf{m N}$ & $\mathbf{m E}$ & Elevasi (m) & $\begin{array}{c}\text { Azimuth } \\
\left(\mathbf{N} . . .{ }^{\circ} \mathbf{E}\right)\end{array}$ & $\begin{array}{c}\text { Kemiringan } \\
\left(\ldots{ }^{\circ}\right)\end{array}$ & Panjang (m) \\
\cline { 2 - 5 } GT01 & 173179.68 & 735031.34 & 82 & 270 & 60 & 250.2 \\
\hline GT02 & 172977.64 & 735148.46 & 103.87 & 230 & 65 & 239.1 \\
\hline GT03 & 173186.17 & 735246.57 & 97.78 & 110 & 70 & 268.1 \\
\hline
\end{tabular}




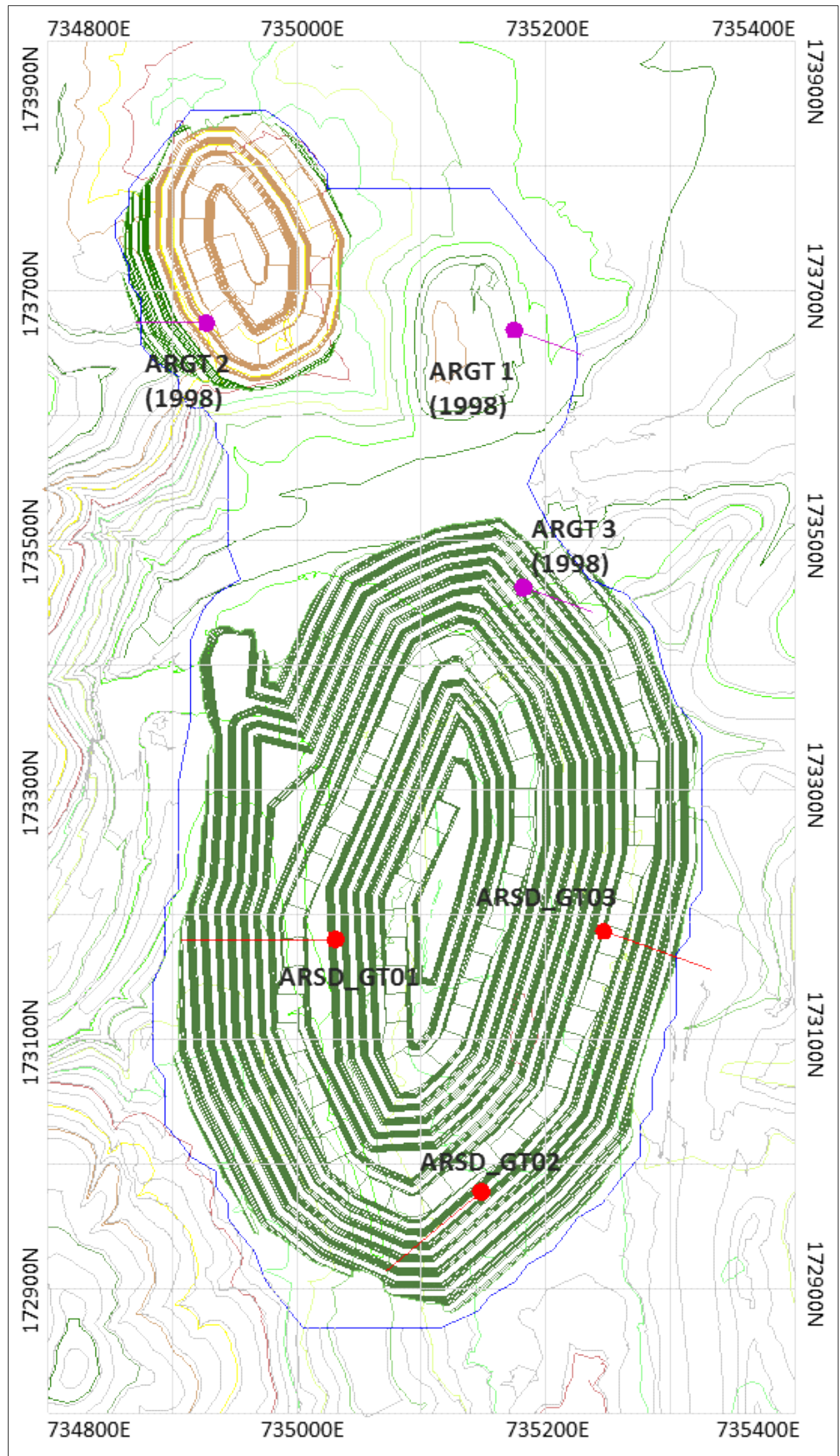

Gambar 3. Posisi lubang pemboran geoteknik pada rancangan tambang terbuka Araren (Anonim, 1998). 


\section{MAKALAH ILMIAH}

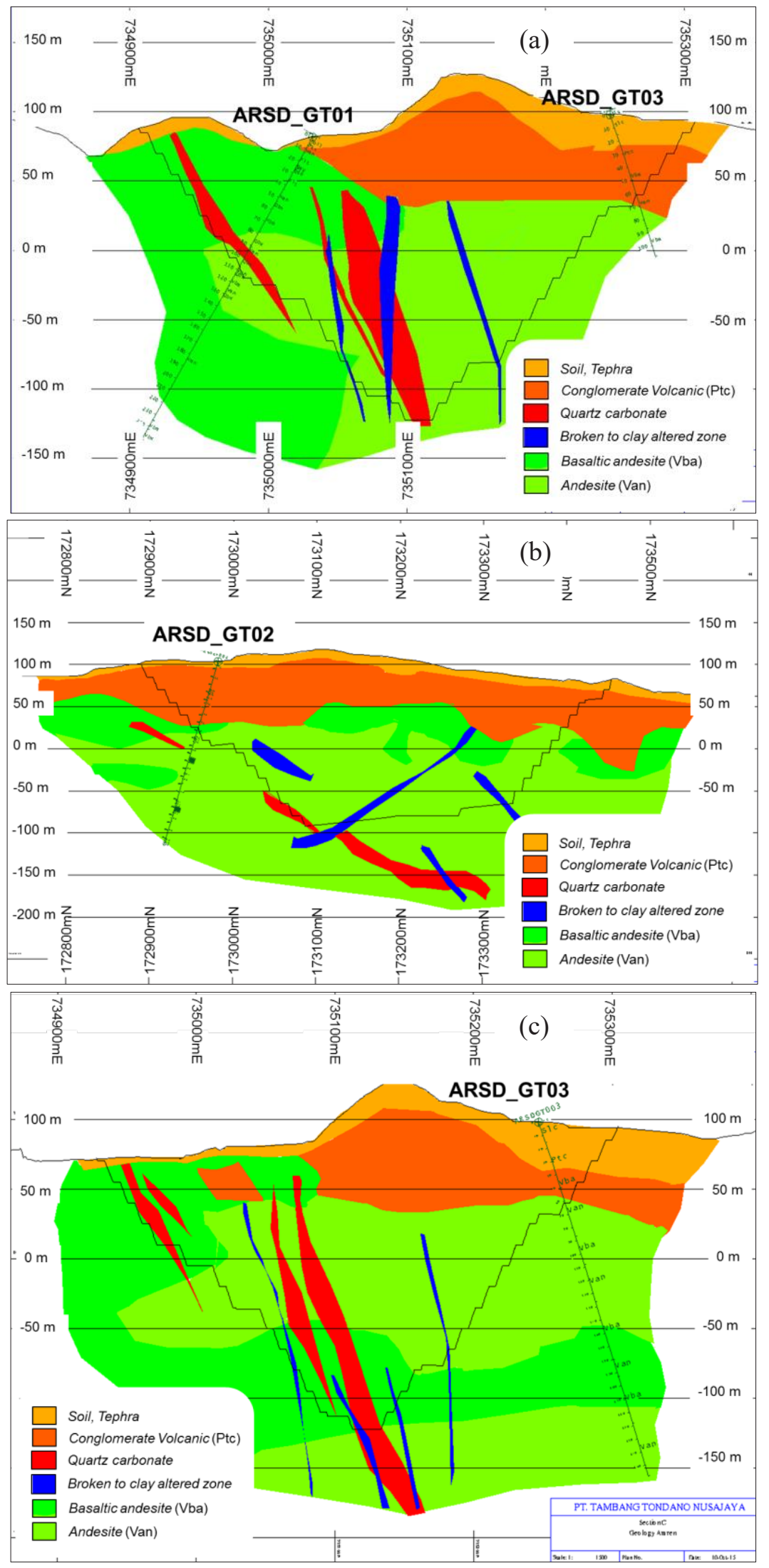

Gambar 4. Penampang melintang (searah lubang bor) dan interpretasi geologi; (a) ARSD_GT01, (b) ARSD_GT02, dan (c) ARSD_GT03. 
Pelaksanaan pemboran. Pemboran inti dimulai pada 18 Maret 2015 dan selesai pada 14 April 2015 dengan total 757,4 m panjang lubang bor. Dilakukan dengan mesin bor Hanjin 7000 rig, menggunakan ukuran standard wireline core barrel PQ3 (diameter inti batuan $83 \mathrm{~mm}$ ) dan HQ3 (diameter inti batuan 61,1 mm), wireline triple-tube untuk memaksimalkan perolehan inti (core recovery). Lumpur pemboran digunakan untuk meningkatkan perolehan inti batuan. Inti batuan yang berhasil diorientasi (menggunakan alat digital ORIFINDER Core Orientation System) diberikan tanda pada bagian dasar lubang. Tanda ini digunakan untuk menggambar garis lurus sebagai referensi di sepanjang inti batuan hasil pemboran. Inti batuan dihasilkan dari lubang bor diletakkan pada rel besi baja berbentuk $\mathrm{V}$ untuk memudahkan saat pengambilan dan pengukuran data. Panjang inti batuan hasil pemboran (run) di lokasi pengamatan bervariasi mulai dari $40 \mathrm{~cm}$ hingga maksimum 1,5 $\mathrm{m}$. Kondisi batuan yang menguntungkan dan teknik pemboran yang baik dapat memberikan panjang inti batuan maksimum. Survei kamera dilakukan setiap $30 \mathrm{~m}$ panjang lubang setiap selesai dibor. Gambar 5 (a), (b), dan (c) memperlihatkan kondisi pada penjelasan di atas.
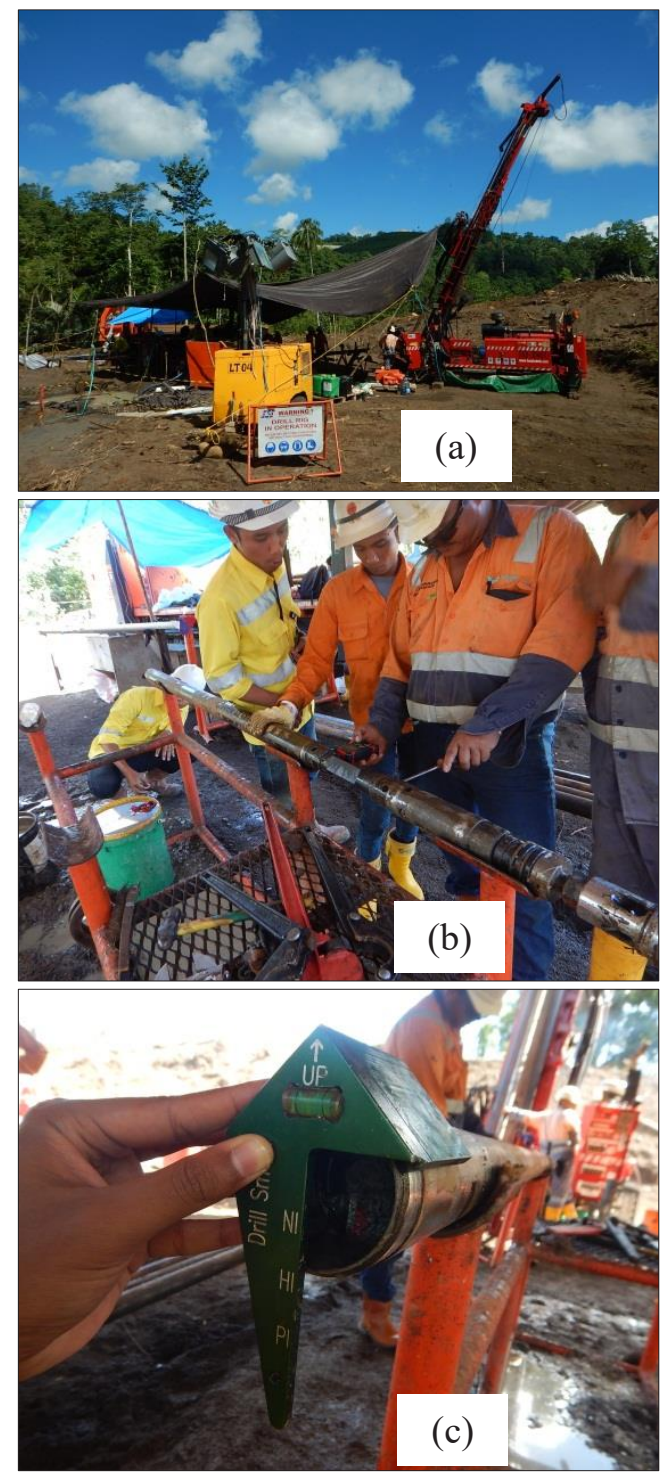

Gambar 5. (a) Pelaksanaan pemboran geoteknik, (b) Orientasi inti batuan menggunakan alat orientasi digital ORIFINDER Core Orientation System, (c) Bagian dasar inti batuan ditandai untuk menentukan garis referensi. 


\section{MAKALAH ILMIAH}

Pengumpulan data (logging) Pengumpulan data pemboran, massa batuan, dan bidang diskontinuitas dilakukan sebelum inti batuan hasil pemboran dimasukkan ke dalam kotak penyimpanan (core box). Inti batuan yang diorientasi menggunakan metoda alfa (dapat memakai busur derajat) dan beta
(Gambar 6) memakai protractor yang tersedia (Gambar 7). Dokumentasi foto dilakukan dengan menyertakan nama lubang bor, tanggal, kedalaman dan interval panjang lubang bor, serta nomor kotak penyimpanan. Semua inti batuan disimpan di Core Shed (Gambar 8).

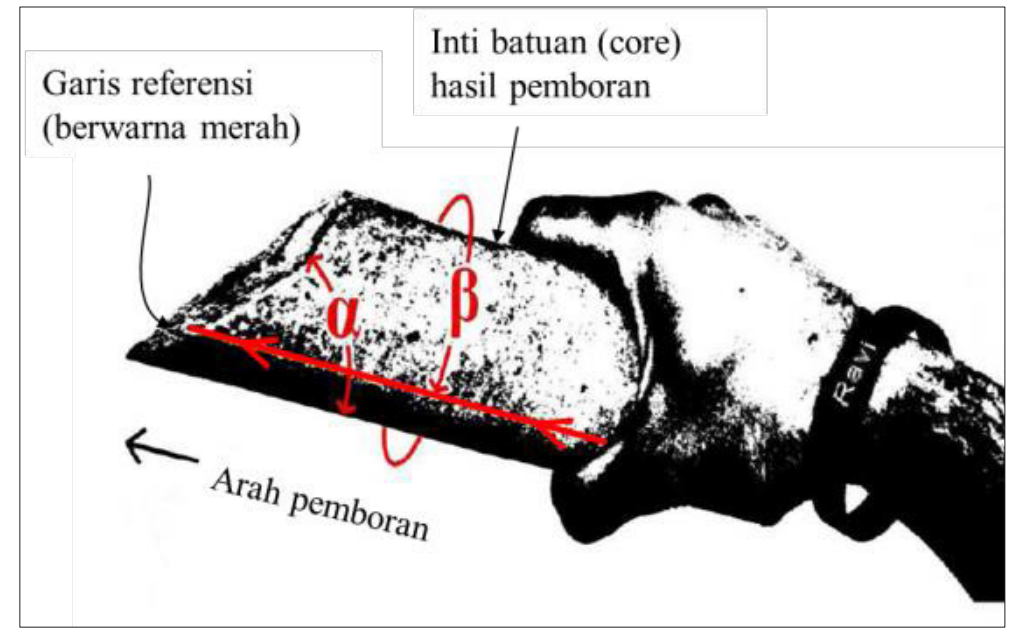

Gambar 6. Pengukuran sudut alfa dan beta pada inti batuan (Cylwik et al., 2011, dalam Ureel et al., 2013).

Keterangan : Sudut alfa $(\alpha)$ adalah besaran sudut antara sumbu inti batuan terhadap kemiringan bidang diskontinuitas, berkisar antara $0^{\circ}$ dan $90^{\circ}$. Sudut beta $(\beta)$ adalah besaran sudut di sekeliling inti batuan antara garis referensi (ditandai pada bagian bawah inti batuan dengan alat Orifinder) dan bagian ujung elips atau besar kemiringan maksimum bidang diskontinuitas, berkisar antara $0^{\circ}$ dan $360^{\circ}$. Metoda pengukuran $\beta$ selalu melihat ke arah pemboran.

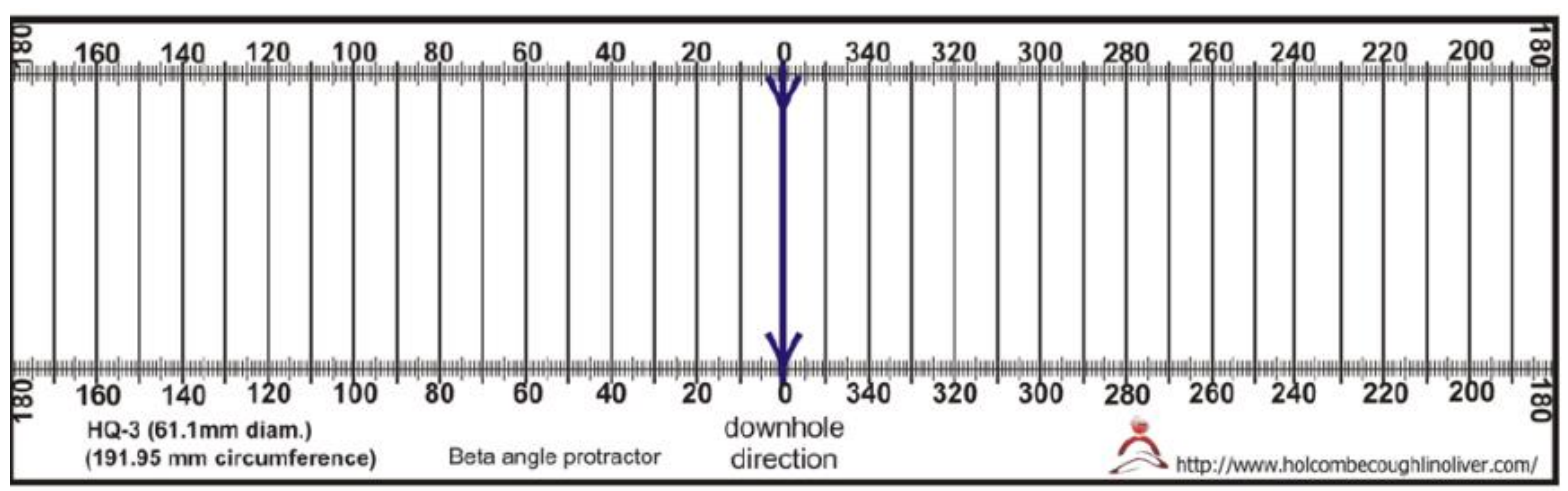

Gambar 7. Protractor untuk mengukur sudut beta (HCO, 2010).

Pengolahan data. Orientasi bidang diskontinuitas yang terukur pada inti batuan hasil pemboran (alfa, $\alpha$ dan beta, $\beta$ ) dikonversi menjadi kemiringan dan arah kemiringan sebenarnya di alam (dip dan dip direction) memakai perangkat lunak DIPS versi 6.016 (Rocscience, 2014). 


\section{MAKALAH ILMIAH}

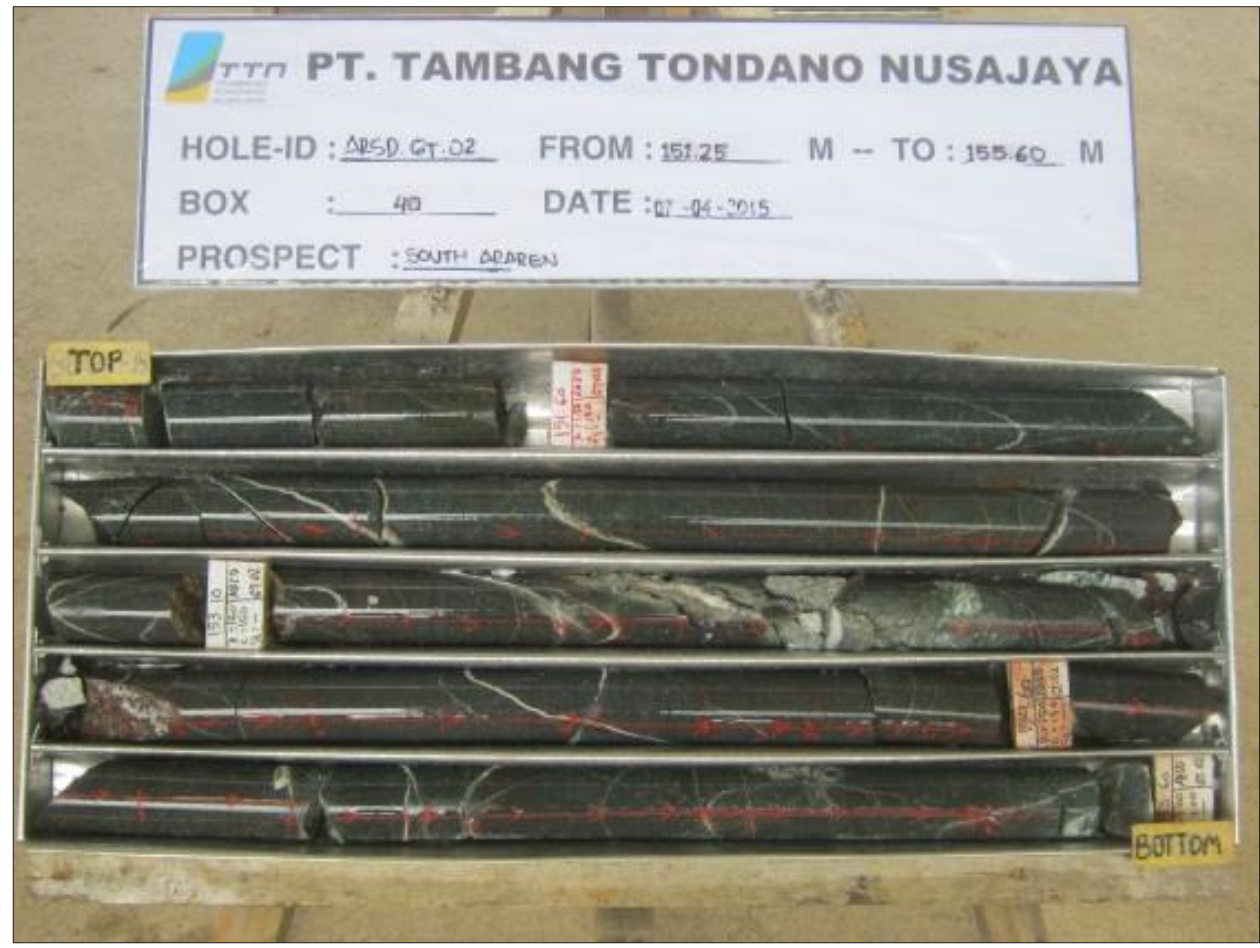

Gambar 8. Dokumentasi foto inti batuan di Core Shed.

\section{Hasil dan Pembahasan}

Orientasi inti batuan (pengukuran alfa dan beta) dilakukan dengan baik pada lubang pemboran ARSD_GT01 yang pertemuannya dengan rancangan lereng tambang terjadi pada batuan Andesit. Kondisi berbeda pada lubang bor ARSD_GT02 dan 03 yang terdapat kontak litologi antara konglomerat vulkanik dengan Andesit dan Basalt. Pada Tabel 2 di bawah memperlihatkan ringkasan orientasi inti batuan lebih baik di ARSD GT01. Beberapa kegagalan melakukan orientasi bidang diskontinuitas disebabkan karena tidak dapat meletakkan tanda dan garis referensi pada inti batuan yang rusak atau hancur.

Tabel 2. Ringkasan orientasi inti batuan

\begin{tabular}{|c|c|c|c|c|c|c|}
\hline \multirow{2}{*}{$\begin{array}{c}\text { Nomor ARSD } \\
\text { Lubang Bor }\end{array}$} & \multicolumn{2}{|c|}{$\begin{array}{c}\text { Pengamatan pada meter } \\
\text { pemboran }\end{array}$} & \multirow{2}{*}{$\begin{array}{c}\text { Total } \\
\text { panjang inti } \\
\text { batuan }(\mathrm{m})\end{array}$} & \multirow{2}{*}{$\begin{array}{c}\text { Panjang inti } \\
\text { batuan yang } \\
\text { diorientasi }(m)\end{array}$} & \multirow{2}{*}{$\begin{array}{c}\text { Persentasi inti } \\
\text { batuan yang } \\
\text { diorientasi }\end{array}$} & \multirow{2}{*}{$\begin{array}{c}\text { Total bidang } \\
\text { diskontinuitas } \\
\text { yang diorientasi }\end{array}$} \\
\hline & Dari (m) & Ke (m) & & & & \\
\hline GT01 & 95.36 & 126.76 & 31.4 & 30.4 & 97 & 193 \\
\hline GT02 & 80.65 & 110.19 & 29.54 & 15.64 & 53 & 87 \\
\hline GT03 & 48.55 & 90.2 & 41.65 & 15.15 & 36 & 35 \\
\hline
\end{tabular}

Tabel 3 memperlihatkan hasil olahan pilihan data orientasi alfa dan beta menjadi dip dan dip direction bidang diskontinuitas, yang terletak dekat dengan lereng tambang terbuka. Merujuk kepada hasil uji laboratorium (Anonim, 1998), bahwa nilai sudut geser dalam $30^{\circ}$ dapat dipakai untuk analisis kinematik pada tahap rancangan lereng tambang terbuka. Syarat terbentuknya model longsoran bidang, baji, dan rebah dapat terjadi di setiap lokasi pengamatan lubang bor. Model longsoran baji berpeluang paling besar untuk terjadi, kemudian berturutturut diikuti dengan model longsoran bidang serta model longsoran rebah. Pada stereonet memperlihatkan masing-masing analisis kinematik pada setiap lubang bor dan lereng tambang (Tabel 4 dan Gambar 10). 


\section{MAKALAH ILMIAH}

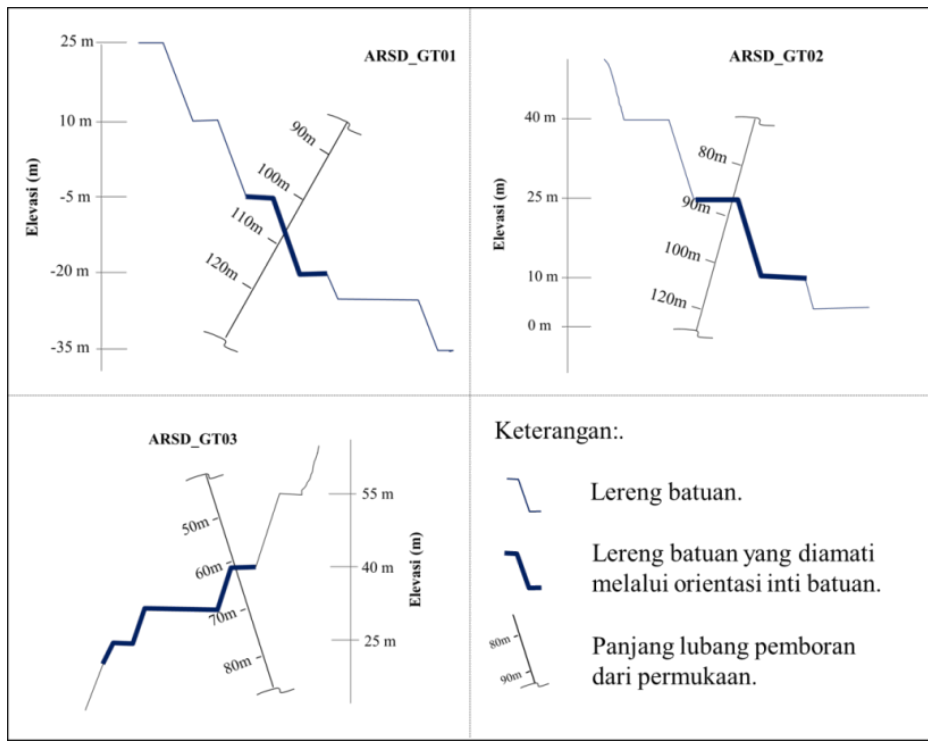

Gambar 9. Pengamatan lereng melalui pemboran dan orientasi inti batuan (merujuk pada Gambar-3, sketsa tanpa skala).

Tabel 3. Ringkasan hasil pengolahan data alfa dan beta menggunakan perangkat lunat DIPS versi 6.016.

\begin{tabular}{|c|c|c|c|c|c|c|c|c|c|c|c|c|c|c|c|}
\hline \multicolumn{6}{|c|}{$\begin{array}{c}\text { ARSD-GT.01 } \\
\text { Kemiringan lubang bor: } 60^{\circ} \\
\text { Azimuth: } 270^{\circ}\end{array}$} & \multicolumn{5}{|c|}{$\begin{array}{c}\text { ARSD-GT.02 } \\
\text { Kemiringan lubang bor: } 65^{\circ} \\
\text { Azimuth: } 230^{\circ}\end{array}$} & \multicolumn{5}{|c|}{$\begin{array}{c}\text { ARSD-GT.03 } \\
\text { Kemiringan lubang bor: } 70^{\circ} \\
\text { Azimuth: } 110^{\circ}\end{array}$} \\
\hline No & $\begin{array}{l}\text { Kedala } \\
\text { man }(\mathrm{m})\end{array}$ & Alfa & Beta & Dip & Dip Dir. & $\begin{array}{l}\text { Kedala } \\
\text { man }(\mathrm{m})\end{array}$ & Alfa & Beta & Dip & Dip Dir. & $\begin{array}{l}\text { Kedala } \\
\text { man (m) }\end{array}$ & Alfa & Beta & Dip & Dip Dir. \\
\hline 1 & 95,36 & 50 & 150 & 20 & 197 & 80,65 & 80 & 70 & 30 & 69 & 48,80 & 15 & 130 & 63 & 54 \\
\hline 2 & 95,42 & 40 & 340 & 79 & 75 & 80,68 & 65 & 190 & 4 & 325 & 48,90 & 30 & 80 & 65 & 360 \\
\hline 3 & 95,57 & 60 & 60 & 51 & 124 & 80,84 & 30 & 30 & 84 & 67 & 49,00 & 25 & 30 & 83 & 317 \\
\hline 34 & 100,02 & 45 & 120 & 38 & 176 & 89,14 & 18 & 350 & 83 & 220 & 90,00 & 5 & 275 & 87 & 206 \\
\hline 35 & 100,48 & 40 & 140 & 32 & 201 & 89,20 & 52 & 355 & 63 & 47 & 90,20 & 20 & 120 & 61 & 42 \\
\hline 36 & 100,51 & 40 & 140 & 32 & 201 & 90,82 & 52 & 50 & 57 & 84 & & & & & \\
\hline 85 & 109,60 & 40 & 350 & 80 & 82 & 109,99 & 31 & 40 & 79 & 84 & & & & & \\
\hline 86 & 109,77 & 22 & 10 & 82 & 279 & 110,07 & 40 & 75 & 60 & 109 & & & & & \\
\hline 87 & 110,18 & 35 & 340 & 84 & 74 & 110,19 & 65 & 160 & 8 & 131 & & & & & \\
\hline 88 & 110,56 & 40 & 335 & 78 & 71 & & & & & & & & & & \\
\hline 192 & 126,24 & 40 & 260 & 51 & 15 & & & & & & & & & & \\
\hline 193 & 126,76 & 40 & 340 & 79 & 75 & & & & & & & & & & \\
\hline
\end{tabular}

Tabel 4. Hasil analisa kinematik perangkat lunat DIPS versi 6.016.

\begin{tabular}{|c|c|c|c|c|c|c|c|}
\hline $\begin{array}{c}\text { Nomor } \\
\text { ARSD } \\
\text { Lubang } \\
\text { Bor }\end{array}$ & $\begin{array}{c}\text { Elevasi } \\
\text { lereng } \\
\text { batuan }(m)\end{array}$ & $\begin{array}{r}\text { Kemiringan } \\
\text { lereng }\left(. .{ }^{\circ}\right)\end{array}$ & $\begin{array}{c}\text { Arah } \\
\text { kemiringan } \\
\text { lereng } \\
(\mathbf{N} . . . \% / \mathbf{E})\end{array}$ & $\begin{array}{c}\text { Model } \\
\text { longsoran }\end{array}$ & $\begin{array}{l}\text { Jumlah bidang } \\
\text { diskontinuitas } \\
\text { yang diamati }{ }^{*}\end{array}$ & $\begin{array}{c}\text { Jumlah } \\
\text { potensi } \\
\text { longsor } \\
\text { (bahaya } \\
\text { lereng) }\end{array}$ & $\begin{array}{c}\text { Persentase } \\
\text { jumlah } \\
\text { potensi } \\
\text { longsor }(\%)\end{array}$ \\
\hline \multirow{3}{*}{ GT01 } & \multirow{3}{*}{-5 ke -20} & \multirow{3}{*}{70} & \multirow{3}{*}{90} & Bidang & 193 & 23 & 11,9 \\
\hline & & & & Rebah & 193 & 8 & 4,1 \\
\hline & & & & Baji & 18.484 & 4.681 & 25,3 \\
\hline \multirow{3}{*}{ GT02 } & \multirow{3}{*}{25 ke 10} & \multirow{3}{*}{70} & \multirow{3}{*}{25} & Bidang & 87 & 6 & 6,9 \\
\hline & & & & Rebah & 87 & 1 & 1,1 \\
\hline & & & & Baji & 3,738 & 817 & 21,9 \\
\hline \multirow{3}{*}{ GT03 } & \multirow{3}{*}{40 ke 25} & \multirow{3}{*}{70} & \multirow{3}{*}{310} & Bidang & 35 & 5 & 14,3 \\
\hline & & & & Rebah & 35 & 3 & 8,6 \\
\hline & & & & Baji & 585 & 214 & 36,6 \\
\hline
\end{tabular}

${ }^{*}$ Model longsoran baji:

Jumlah kombinasi pasangan dari setiap bidang diskontinuitas yang diamati. 


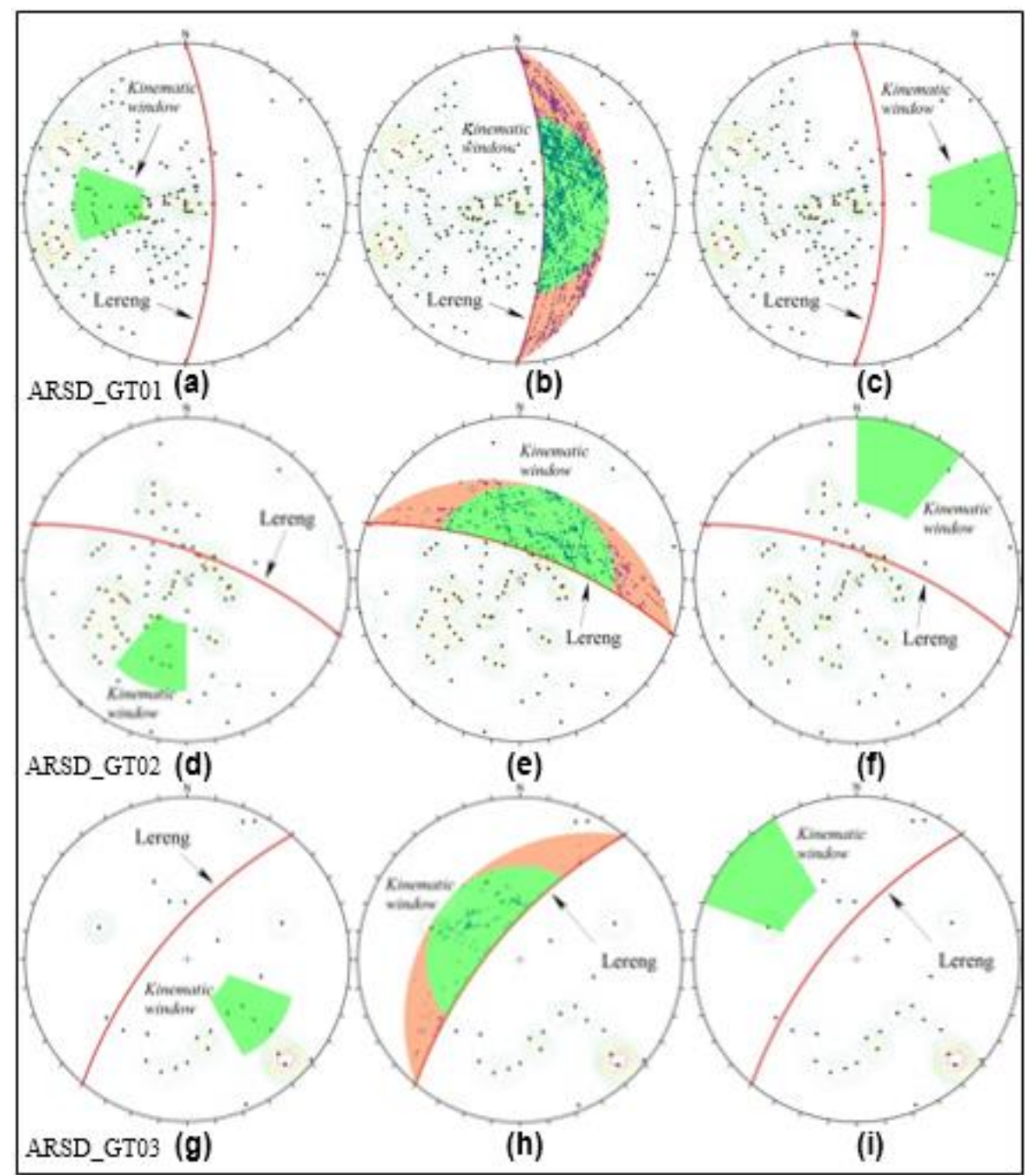

Gambar-10. Stereonet bidang diskontinuitas hasil dari orientasi inti batuan dengan perangkat lunak DIPS versi 6.016 di ARSD_GT01, ARSD_GT02, dan ARSD_GT03: (a), (d), dan (g) potensi model longsoran bidang; (b), (e) dan (h) potensi model longsoran baji; (c), (f) dan (i) potensi model longsoran rebah.

\section{Kesimpulan Dan Saran}

\section{Kesimpulan}

Orientasi inti batuan dapat digunakan untuk mendapatkan nilai dip dan dip direction bidang diskontinuitas bawah permukaan dari inti pemboran geoteknik.

Dari pemboran geoteknik ARSD_GT01, 02, dan 03 di lokasi tambang Araren dapat dipetakan distribusi bidang diskontinuitas yang dapat dipakai untuk penentuan potensi bahaya longsor pada lereng tambang dengan menggunakan stereonet.

Dari kajian kemantapan lereng di lokasi pengamatan didapat adanya potensi longsoran bidang, baji, dan rebah pada saat penambangan terbuka dilakukan.

\section{Saran}

Pengukuran bidang diskontinuitas di permukaan (pemetaan geologi teknik) diperlukan untuk mendukung kajian bidang diskontinuitas di bawah permukaan yang dapat dilakukan apabila telah dilakukan penambangan terbuka.

Diperlukan uji laboratorium untuk menentukan nilai kuat geser dan parameter kekuatan batuan lainnya di lokasi pengamatan untuk analisa kemantapan lereng batuan yang lebih komprehensif. 


\section{MAKALAH ILMIAH}

\section{Ucapan Terima Kasih}

Terima kasih yang tidak terhingga penulis ucapkan kepada pihak PT Tambang Tondano Nusajaya atas kesempatan yang diberikan untuk melaksanakan penelitian di lokasi proyek tambang emas Araren.

\section{Daftar Pustaka}

Anonim, 1998. Araren - Geotechnical Studies. Laporan internal Coffey Mining Consultant, PT Tambang Tondano Nusajaya, Toka Tindung Project, tidak dipublikasi.

Anonim, 2006. Kajian Kelayakan Proyek Emas Batupangah. Laporan internal tidak dipublikasi.

Anonim, 2014. PT Meares Soputan Mining and PT Tambang Tondano Nusajaya Exploration Monthly December 2014 Report. Laporan internal tidak dipublikasi.

Anonim, 2015. PT Meares Soputan Mining and PT Tambang Tondano Nusajaya Exploration Monthly September 2015 Report. Laporan internal tidak dipublikasi.

Grose, P.J. 1997. Batupangah Gold Project Feasibility Study, Appendix B - Part 1. PT Tambang Tondano Nusajaya, Laporan internal tidak dipublikasi.

HCO. 2010. HCO oriented core templates. Diunduh dari http://www.holcom becoughlinoliver.com/.

HCO. 2011. Oriented drillcore: measurement and calculation procedures for structural and exploration geologist, Diunduh dari http://www.holcombecoughlinoliver. $\mathrm{com} /$.

Lockett, N.H. 1996. Photogeological Interpretation of Black \& White 1:30,000 Aerial Photographs and SPOT Imagery. Unpublished report to PT Aurora Gold Indonesia, Toka Tindung Project, North Sulawesi.

Rocscience. 2014. Oriented Core and Rock Mass Classification. Perangkat lunak DIPS tutorial. Diunduh dari https://www.rocscience.com/help/dip s/webhelp/pdf files/tutorials/Tutorial 05 Oriented Core and Rock Mas s Classification.pdf

Ureel S., Momayez M., Oberling Z. 2013. Rock Core Orientation for Mapping Discontinuities and Slope Stability Analysis. IJRET: International Journal of Research in Engineering and Technology. Volume 02.

Wyllie, D.C., \& Mah, C.W. 2004. Rock Slope Engineering, 4th edition. Spon Press.

$\begin{array}{ll}\text { Diterima } & : \text { 3 September } 2015 \\ \text { Direvisi } & : 6 \text { Oktober } 2015 \\ \text { Disetujui } & : \text { 26 November } 2015\end{array}$

